\title{
Bromovirus Movement Protein Conditions for the Host Specificity of Virus Movement Through the Vascular System and Affects Pathogenicity in Cowpea
}

\author{
Yasunari Fujita, ${ }^{1}$ Miki Fujita, ${ }^{1}$ Kazuyuki Mise, ${ }^{1}$ Takashi Kobori, ${ }^{2}$ Takeshi Osaki, ${ }^{2}$ and Iwao Furusawa ${ }^{1}$ \\ ${ }^{1}$ Laboratory of Plant Pathology, Graduate School of Agriculture, Kyoto University, Kyoto 606-8502, Japan; \\ ${ }^{2}$ Laboratory of Plant Pathology, College of Agriculture, Osaka Prefecture University, Sakai 599-8531, Japan. \\ Accepted 17 July 2000.
}

Previously, we reported that $\operatorname{CCMV(B3a),~a~hybrid~of~}$ bromovirus Cowpea chlorotic mottle virus (CCMV) with the 3a cell-to-cell movement protein (MP) gene replaced by that of cowpea-nonadapted bromovirus Brome mosaic virus (BMV), can form small infection foci in inoculated cowpea leaves, but that expansion of the foci stops between 1 and 2 days postinoculation. To determine whether the lack of systemic movement of $\operatorname{CCMV}(\mathrm{B3a})$ is due to restriction of local spread at specific leaf tissue interfaces, we conducted more detailed analyses of infection in inoculated leaves. Tissue-printing and leaf press-blotting analyses revealed that $\mathrm{CCMV}(\mathrm{B3a})$ was confined to the inoculated cowpea leaves and exhibited constrained movement into leaf veins. Immunocytochemical analyses to examine the infected cell types in inoculated leaves indicated that $\operatorname{CCMV(B3a)~was~able~to~reach~the~bundle~sheath~cells~}$ through the mesophyll cells and successfully infected the phloem cells of $50 \%$ of the examined veins. Thus, these data demonstrate that the lack of long-distance movement of $\mathrm{CCMV}(\mathrm{B3a})$ is not due to an inability to reach the vasculature, but results from failure of the virus to move through the vascular system of cowpea plants. Further, a previously identified 3a coding change (A776C), which is required for $\mathrm{CCMV}(\mathrm{B3a})$ systemic infection of cowpea plants, suppressed formation of reddish spots, mediated faster spread of infection, and enabled the virus to move into the veins of inoculated cowpea leaves. From these data, and the fact that $\mathrm{CCMV}(\mathrm{B3a})$ directs systemic infection in Nicotiana benthamiana, a permissive systemic host for both BMV and CCMV, we conclude that the bromovirus 3a MP engages in multiple activities that contribute substantially to host-specific long-distance movement through the phloem.

Corresponding author: K. Mise; Telephone: +81-75-753-6132; Fax: +81-75-753-6131; E-mail: kmise@ kais.kyoto-u.ac.jp

Current address of Yasunari Fujita: Biological Resources Division, Japan International Research Center for Agricultural Sciences (JIRCAS), Ministry of Agriculture, Forestry and Fisheries, 1-2 Ohwashi, Tsukuba, Ibaraki 305-8686, Japan.

Current address of M. Fujita: Plant Mutation Exploration Team, Plant Functional Genomics Research Group, RIKEN Genomic Sciences Center, 3-1-1 Koyadai, Tsukuba, Ibaraki 305-0074, Japan.
Systemic infection of plants by viruses is a multistep process involving movement through several distinct cell and tissue boundaries (Carrington et al. 1996; Hull 1991; Lucas and Gilbertson 1994; Maule 1991; Nelson and van Bel 1998). First, viruses must replicate in the initially infected epidermal cells and then invade adjacent cells through intercellular plasmodesmatal connections. Second, viruses must move through mesophyll and bundle sheath cells and traverse the vascular system for long-distance transport to other organs. Finally, the viruses must exit from the vasculature and reestablish multiplication and cell-to-cell movement in the distal tissues.

Viral cell-to-cell spread requires virus-encoded movement proteins (MPs) that target the plasmodesmata and modify the size exclusion limit of the plasmodesmal core (Atabekov and Taliansky 1990; Citovsky and Zambryski 1991; Deom et al. 1992; Ding 1998; Ghoshroy et al. 1997; Lazarowitz and Beachy 1999; Lucas and Wolf 1999). Although substantial progress has been achieved in our understanding of MPmediated cell-to-cell movement, the role of the MP gene in long-distance movement via the vascular system remains poorly understood (Gilbertson and Lucas 1996; Santa Cruz 1999; Séron and Haenni 1996). Recently, in Cucumber mosaic virus (CMV), the 3a MP gene has been shown to be directly involved in the final stages of virus entry into the minor phloem veins (Blackman et al. 1998). However, the mechanisms whereby the MP specifies long-distance transport remain to be determined.

Cowpea chlorotic mottle virus (CCMV) and Brome mosaic virus (BMV) are two closely related members of the genus Bromovirus, which comprises a group of icosahedral, tripartite, positive-strand RNA viruses of plants (Murphy 1996). RNA1 and RNA2 encode the 1a and 2a proteins, respectively, that are required for viral RNA replication in protoplasts (French et al. 1986; Kiberstis et al. 1981). RNA3 encodes the 3a MP and the viral coat protein (CP), which is expressed from subgenomic RNA4 (Miller et al. 1985; Allison et al. 1990). The 3a MP has been shown to be localized to plasmodesmata (Fujita et al. 1998), to bind nucleic acid in vitro (Fujita et al. 1998, 1999a; Jansen et al. 1998), and to be involved in cell-to-cell spread (Mise and Ahlquist 1995; Schmitz and Rao 1996), host-specific long-distance movement (De Jong et al. 1995; Fujita et al. 1996, 1999b; Mise et al. 1993), and symptom development (Fujita et al. 1996; Rao 
and Grantham 1995). The CCMV CP is dispensable for cellto-cell movement, but is required for long-distance transport (Allison et al. 1990; Rao 1997). CCMV and BMV selectively infect dicotyledonous legumes, such as cowpea, and monocotyledonous grasses, such as barley, respectively, while both viruses can establish systemic infections in Nicotiana benthamiana (Mise et al. 1993; Osman et al. 1997).

A CCMV chimera (CCMV(B3a)) with the 3a cell-to-cell MP gene replaced by that of cowpea-nonadapted BMV replicates well in cowpea protoplasts and can systemically infect $N$. benthamiana but is unable to infect cowpea plants systemically (De Jong et al. 1997; Fujita et al. 1996; Mise et al. 1993). However, approximately $10 \%$ of the inoculated plants developed systemic infections due to the appearance of mutants from the chimeric virus (Fujita et al. 1996; Mise et al. 1993). Sequence analysis of cloned derivatives of the cowpeaadapted $\mathrm{CCMV}(\mathrm{B} 3 \mathrm{a})$ revealed considerable sequence variation, suggestive of movement as a quasispecies; but, interestingly, all of the adaptive clones examined had an A to $\mathrm{C}$ transversion at nucleotide 776 within the BMV $3 a$ gene (Fujita et al. 1999b). In situ hybridization analyses indicated that the unadapted $\mathrm{CCMV}$ (B3a) chimeric virus spread from cell to cell for the first 1 to 2 days postinoculation in the epidermis of inoculated primary leaves, but failed to reach the uninoculated upper trifoliate leaves (Fujita et al. 1996; Mise and Ahlquist 1995; Mise et al. 1993). However, a single codon change in the $3 \mathrm{a}$ MP gene of one of the cowpea-adapted chimeric clones (YF3) conferred the ability to mediate systemic infections of cowpea (Fujita et al. 1996). A related study comparing the cowpea-adapted BMV M2 and cowpea-nonadapted BMV M1 strains also demonstrated that coding changes in the $3 \mathrm{a}$ gene are associated with the adaptation to cowpea (De Jong et al. 1995). In contrast, replacement of CP genes between BMV and CCMV, or between the BMV M1 and M2 strains, does not affect the host ranges of the substituted derivatives (De Jong et al. 1995; Osman et al. 1997). Thus, unlike the CP, the bromovirus 3a MP provides a crucial host-specific determinant for systemic infection.

In the current study, to elucidate the nature of the $3 \mathrm{a}$ genemediated, host-specific restriction of virus movement and the role of the A776C substitution in the 3a gene (Fujita et al. 1996) in adaptation of the chimera to cowpea, we analyzed the infection phenotypes in cowpea inoculated with CCMV,
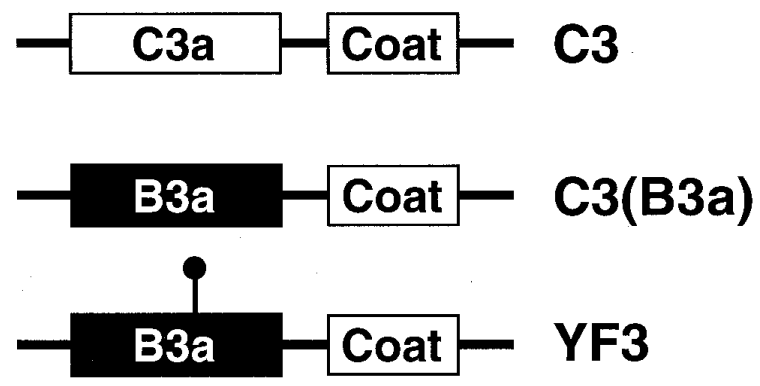

Fig. 1. Schematic representation of wild-type Cowpea chlorotic mottle virus (CCMV) RNA3 (C3), hybrid RNA C3(B3a), and its derivative YF3, which contains the A776C adaptive substitution in C3(B3a). C3 is shown with boxes representing the wild-type CCMV 3a protein gene (C3a) and coat protein (coat) genes and single lines representing noncoding sequences. The Brome mosaic virus 3a gene (B3a) in the RNA3 hybrid $\mathrm{C} 3(\mathrm{~B} 3 \mathrm{a})$ is illustrated by a closed box.
CCMV(B3a), and the mutant containing the A776C substitution. Our findings reveal that the failure of $\operatorname{CCMV(B3a)~to~}$ establish systemic infection of cowpea is a consequence of restricted movement through the vascular system. This result demonstrates that the bromovirus $3 \mathrm{a}$ gene is a substantial component in host-specific long-distance phloem movement. The role of the A776C mutation in circumventing this blockage is discussed.

\section{RESULTS}

Time course of viral exit from inoculated primary leaves and confinement of $\mathrm{CCMV}(\mathrm{B3a})$ infection spread to inoculated leaves.

The CCMV RNA3 mutants used in this study are diagrammed in Figure 1. These include wild-type CCMV RNA3 (C3); a chimeric virus, C3(B3a), in which the wild-type CCMV 3a gene is replaced by that of BMV; and a mutant YF3, which contains a single base substitution (A776C) in the BMV 3a MP gene of C3(B3a). The A776C substitution leads to a Serine-to-Arginine amino acid change at position 180 in the 3 a protein that permits $\mathrm{C} 3(\mathrm{~B} 3 \mathrm{a})$ to establish systemic infections of a restriction host, cowpea (Fujita et al. 1996, 1999b). In vitro transcripts of each of these three RNA3 mutant clones in combination with wild-type CCMV RNA1 (C1) and RNA2 (C2) were tested for their ability to infect cowpea plants in all subsequent experiments.

We have previously shown that $100 \%$ of the cowpea plants inoculated with $\mathrm{C} 3$ or with YF3 developed systemic infections (Fujita et al. 1996). In contrast, the chimeric C3(B3a) derivative infected only inoculated primary leaves and failed to reach the upper trifoliate leaves (Mise et al. 1993; Mise and Ahlquist 1995; Fujita et al. 1996). Our previous results, however, did not rule out the possibility that $\mathrm{C} 3$ (B3a) infections might enter the vasculature of the inoculated leaves, move systemically, and be constrained from exiting into the upper uninoculated leaves. In order to determine which step or steps of the C3(B3a) infection is interrupted, and to further characterize the systemic infection phenotypes of $\mathrm{C} 3$ and YF3, a kinetic analysis of infection was conducted using tissueprinting assays. The two primary leaves were inoculated with C3(B3a), YF3, or C3, and then removed at 1, 2, 3, 4, 6, and 8 days postinoculation (dpi). Two weeks after inoculation, cross sections from the rolled first trifoliate leaves, the petioles of the first trifoliate leaves, and the stems between the primary inoculated leaves and the first trifoliate leaves were analyzed by tissue printing (Fig. 2). Removal of leaves inoculated with C3 later than 2 dpi or with YF3 later than 3 dpi had no effect on the subsequent systemic movement phenotype, which required transit from the inoculated leaves through stems and trifoliate petioles to reach the upper trifoliate leaves (Fig. 2). This result shows that $\mathrm{C} 3$ exited from primary inoculated leaves between 1 and $2 \mathrm{dpi}$, while the adaptive mutant YF3 exited from inoculated leaves between 2 and 3 dpi. As expected, the chimeric virus $\mathrm{C} 3(\mathrm{~B} 3 \mathrm{a})$ failed to exit from the inoculated leaves during these trials (Fig. 2). Thus, it appears that the initial spread of C3(B3a) was restricted within inoculated cowpea leaves. Therefore, we subsequently conducted experiments to dissect the series of events whereby YF3 containing the A776C mutation exits from the inoculated cowpea leaves. 


\section{A776C 3a coding change alters early local spread in inoculated leaves.}

To examine the possible effects of the A776C 3 a coding change on the rates of cell-to-cell spread in inoculated leaves, the time course of viral RNA accumulation in primary leaves inoculated with C3(B3a), YF3, or C3 was compared by Northern blot analysis. Viral RNAs in leaves inoculated with C3(B3a) increased in abundance up to 4 dpi, decreased afterward, and then tended to remain constant, whereas viral RNAs in YF3 and $\mathrm{C} 3$ infections continued to increase up to $8 \mathrm{dpi}$. Viral RNA accumulation at all time points was lowest in C3(B3a)-, intermediate in YF3-, and increased dramatically in C3-inoculated leaves (Fig. 3). On the basis of measurements from Figure 3 and three other experiments, at $6 \mathrm{dpi}$, viral RNA accumulation in leaves inoculated with YF3 was 3 to $10 \%$ of that with $\mathrm{C} 3$. For inoculations with $\mathrm{C} 3$ (B3a), even at 4 dpi, the peak time point, viral RNA accumulation was approximately $50 \%$ of that in leaves inoculated with YF3 at 2 dpi (Fig. 3). Viral RNA accumulation per infected cowpea cell was nearly constant among these constructs in previous protoplast experiments (Fujita et al. 1996); therefore, these results suggest that YF3 infections spread to new cells more rapidly than infections directed by $\mathrm{C} 3$ (B3a).

To compare local spread in primary inoculated leaves directly, the distribution of viral RNAs was visualized by a leafpress blotting technique (Mansky et al. 1990; Nagano et al. 1997) that uses high pressure to imprint a leaf onto a membrane followed by detection of viral RNA signals by hybridization. Viral RNA signals were first detected in YF3- or C3inoculated leaves as sets of discrete spots at 2 dpi (Fig. 4). By 6 dpi, viral RNAs in C3 infections were distributed throughout most of the leaf, whereas viral RNAs in YF3 infections were detected primarily in association with veins (Fig. 4). In contrast, C3(B3a) was not detected in association with veins, and only localized infection foci were evident by 6 dpi (Fig. 4). Moreover, the patterns or levels of the C3(B3a) RNA signals remained reasonably constant over the next 4 days (data not shown). These press-blotting results demonstrate that the differences in RNA accumulation among three viruses (Fig. 3) are reflected largely by differences in spread of the viruses. Thus, it appears that the A776C adaptive mutation in the YF3 3a MP gene enhances the rate of spread in inoculated cowpea leaves compared with the chimeric C3(B3a). In the leaf pressblotting result of $\mathrm{C} 3(\mathrm{~B} 3 \mathrm{a})$ at $4 \mathrm{dpi}$, the peak time point of viral RNA accumulation in the result of Northern blot analysis (Fig. 3 ), we were unable to see a stronger viral RNA signal than that of any other time point (Fig. 4; data not shown). This might be due to the difference in the efficiency of RNA transfer and hybridization in the leaf press blots versus the Northern blots.

\section{$\operatorname{CCMV(B3a)~encounters~a~block~to~spread~}$ within the vascular system within reddish spots in inoculated leaves.}

Previous in situ hybridization results had demonstrated multiple rounds of cell-to-cell movement in cowpea plants inoculated with C3(B3a). Clusters of 40 to 80 infected cowpea epidermal cells appeared initially, but these foci stopped spreading between 1 and 2 dpi (Mise and Ahlquist 1995). As shown in Figure 3, however, viral RNA accumulation in C3(B3a)-inoculated leaves increased up to 4 dpi. Similar re- sults have also been obtained in earlier experiments (Mise et al. 1993) and in more recent press-blotting analyses (data not shown). These observations suggest that the differential ability to move through cells other than epidermal cells after 2 dpi could account for these diverse results. In this study, we tried to determine whether $\mathrm{C} 3$ (B3a) infects cells other than epidermal cells in the cowpea leaves.

The cell types infected by wild-type C3, YF3, or C3(B3a) were examined microscopically in sections of the inoculated primary leaf tissues containing reddish spots, which were previously identified as infection sites (Mise and Ahlquist 1995). Tissue samples were collected at 7 to $8 \mathrm{dpi}$, fixed, sectioned, and treated with antibody and silver enhancement reactions for CCMV CP detection. The virus was detected in epidermal, mesophyll, and bundle sheath cells in the minor veins (third- or fourth-order veins) of primary leaves inoculated with C3(B3a). Similar patterns were observed in leaves inoculated with C3 or YF3 (Fig. 5A to D; Table 1). However, the virus was detected in the phloem cells of only approximately $50 \%$ of the minor veins of primary leaves inoculated

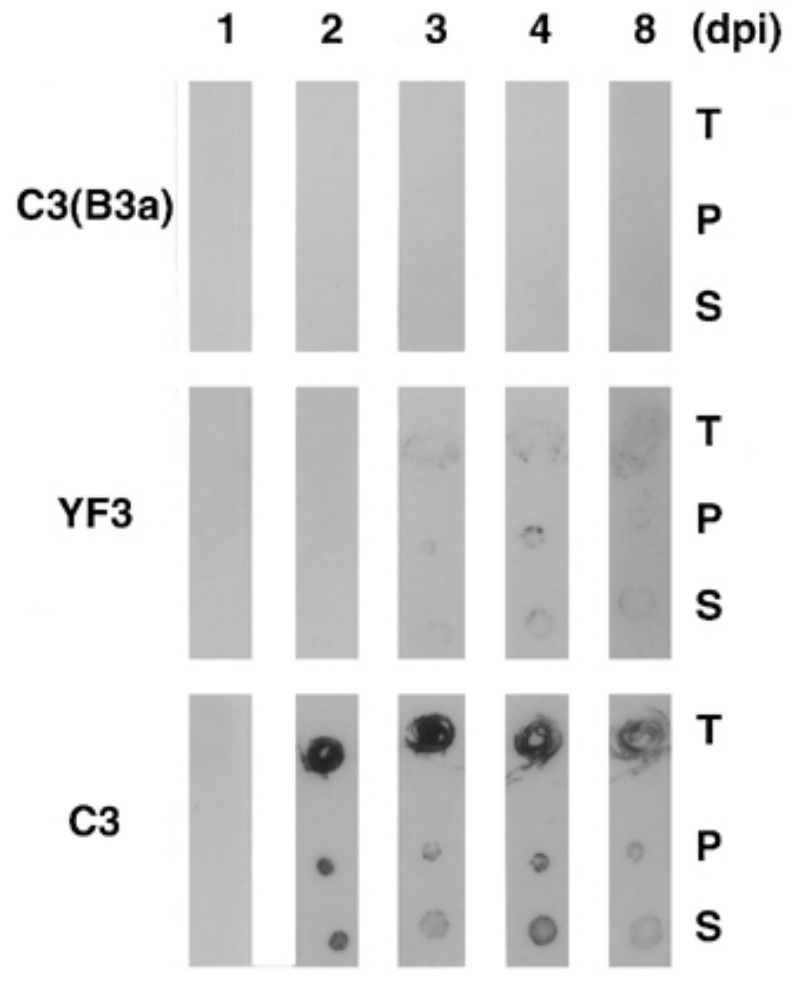

Fig. 2. Tissue-printing assays illustrating viral movement in cowpea plants. Primary leaves of 7- to 9-day-old cowpea seedlings were inoculated with in vitro transcripts of $\mathrm{C} 1+\mathrm{C} 2$ and the RNA3s as shown to the left. Inoculated primary leaves were removed at the number of days postinoculation indicated at the top of the column. Two weeks after inoculation, the first three trifoliate leaflets $(\mathrm{T})$ were detached from the plants and leaves from each sample were stacked into three layers and rolled into a tight cylinder before being cross-sectioned with a razor blade. Subsequently, the petioles of the first trifoliate leaves $(\mathrm{P})$ were cross-sectioned and the stems between the primary inoculated and first trifoliate leaves $(\mathrm{S})$ were cut perpendicular to each axis. Each cut surface was pressed onto a nylon membrane that was then hybridized with a ${ }^{32} \mathrm{P}$ labeled transcript complementary to 179 nucleotides conserved at the $3^{\prime}$ end of each Cowpea chlorotic mottle virus (CCMV) positive-sense RNA before exposing the membrane to X-ray film. 
with C3(B3a), whereas more than $90 \%$ of the minor veins of primary leaves inoculated with wild-type C3 or with YF3 contained detectable signals (Fig. 5A to D; Table 1). Thus, the current data indicate that the failure of $\mathrm{C} 3(\mathrm{~B} 3 \mathrm{a})$ to establish systemic infections is not due to an inability to move to vascular tissues.

\section{A776C 3a coding change suppresses reddish spot formation in inoculated leaves.}

The C3 and C3(B3a) infection phenotypes differed slightly in the types of reddish spots induced on the abaxial and adaxial surfaces of adaxial-inoculated leaves. C3 elicited dark reddish lesions that slowly enlarged to 0.5 to $1.5 \mathrm{~mm}$ in diameter by $8 \mathrm{dpi}$, whereas C3(B3a) generated spots 1 to $2 \mathrm{~mm}$ in diameter. These lesions were initially similar to those appearing after infections by $\mathrm{C} 3$, but they eventually developed chlorotic borders (Fig. 5F and $\mathrm{H}$ ). In contrast to the reddish spot formation elicited by C3(B3a), the adaptive mutant YF3 induced either no visible symptoms or, at most, a small number of reddish flecks. These results indicate that the A776C base substitution resulting in a single amino acid substitution (Ser to Arg) in the BMV 3a MP gene is sufficient to produce a dramatic reduction in the formation of reddish spots in YF3inoculated cowpea leaves (compare Fig. 5G with F).

\section{DISCUSSION}

\section{The 3a MP gene contributes to host-specific movement} through the phloem.

Previous in situ hybridization analyses in cowpea indicated that the CCMV hybrid, CCMV(B3a), initially spread from cell to cell, but stopped spreading when the majority of infection foci encompassed 40 to 80 epidermal cells (Mise and
Ahlquist 1995). This observation raised the possibility that CCMV(B3a) infections were normally arrested prior to interactions with vascular elements (Mise and Ahlquist 1995). The immunocytochemical data presented here, however, indicated that within the reddish spots induced on inoculated leaves, CCMV(B3a) infected epidermal, mesophyll, and bundle sheath cells and also invaded a few phloem cells. Taken together with the data from the tissue-printing and press-blotting analyses, these data demonstrated that $\operatorname{CCMV}(\mathrm{B} 3 \mathrm{a})$ is able to reach the vasculature, but that some interactions restrict the ability of the virus to move through the vascular system in cowpea plants. In addition, the reduced ability of CCMV(B3a) to infect phloem cells and its failure to spread along the veins implied that the restriction occurred both at the bundle sheath-phloem cell boundaries and at the transition pathways from phloem cells to sieve elements.

The blockage of movement at bundle sheath-phloem cell interfaces has been observed in other virus-plant systems. The spread of the soybean strain of CCMV is blocked at this boundary in the soybean line PI346304, which contains recessive resistance genes (Goodrick et al. 1991a, 1991b). Also, in the cucumoviruses, $\mathrm{CMV}$ is unable to negotiate transit from bundle sheath cells to phloem-associated cells in a transgenic tobacco line exhibiting replicase-mediated resistance (Wintermantel et al. 1997) and in highly resistant plants of pepper (Dufour et al. 1989). A similar phenomenon also appears to be responsible for the inability of cucumovirus Tomato aspermy virus to invade cucumber systemically (Thompson and García-Arenal 1998). Additionally, in the case of the masked strain of tobamovirus Tobacco mosaic virus (TMV), a delay in systemic infection of tobacco is presumed to be due to restricted entry into phloem cells (Ding et al. 1995). Interestingly, the MP of TMV has also been shown to
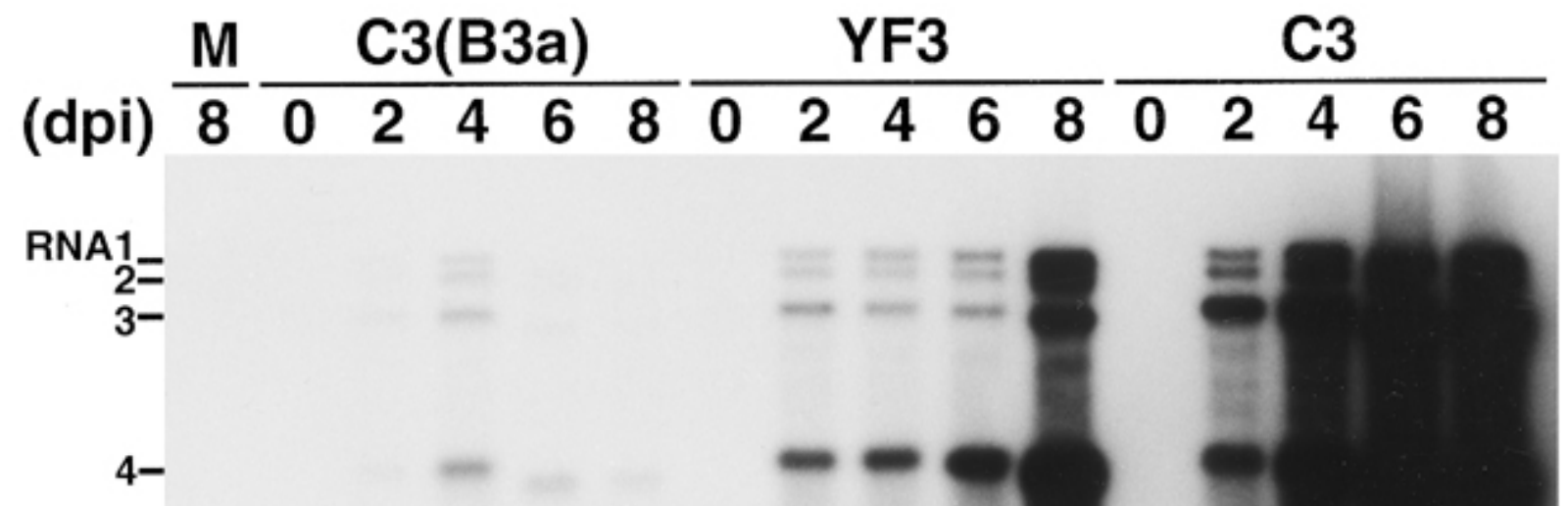

Fig. 3. Time course of viral RNA accumulation in inoculated cowpea leaves. Primary leaves 7 to 9 days after germination were inoculated with buffer (M) or with in vitro transcripts of $\mathrm{C} 1+\mathrm{C} 2$ and the RNA3s indicated above each set of lanes. Six inoculated primary leaves were pooled at the number of days postinoculation indicated above each lane. Total nucleic acids were extracted from each pool, electrophoresed through a $1.5 \%$ agarose gel containing formaldehyde, and then transferred to a nylon membrane. The membrane was hybridized with the same probe used in Figure 2 for detecting positivesense RNAs. Each lane contains equivalent amounts of total leaf nucleic acids (1.5 $\mu \mathrm{g})$. The positions of Cowpea chlorotic mottle virus (CCMV) genomic RNA1, RNA2, and RNA3 and subgenomic RNA4 are shown to the left. 
increase the size exclusion limits of plasmodesmata between mesophyll cells and between mesophyll and bundle sheath cells, but it fails to affect size exclusion limits between bundle sheath and phloem parenchyma cells (Ding et al. 1992). In the cases of the infections of potyvirus Tobacco etch virus (TEV) in a long-distance movement restricting tobacco line V20, and those of helper component proteinase mutants of TEV in Xanthinc, the restriction in long-distance movement were presumed to be associated with entry into or exit from sieve elements (Cronin et al. 1995; Schaad and Carrington 1996). Ding et al. (1988) demonstrated that in tobacco the plasmodesmal connections between phloem companion cells and sieve elements are abundant but, in contrast, those between the companion cell-sieve element complex and vascular parenchyma cells are present in much lower amounts. These observations suggest that the 3a MP gene may directly facilitate host-specific transport through these specialized plasmodesmata. However, our data cannot rule out the possibility that the phloem-dependent movement defect produced by the 3a MP gene may have been indirectly affected by decreases in the rate of cell-to-cell movement (Fig. 3) or restriction of cellto-cell movement in epidermal cells (Mise and Ahlquist 1995).
Overall, our current data verify and extend previous results that a cowpea-nonadapted BMV 3a gene substitution for the cowpea-adapted CCMV 3a gene results in limited cell-to-cell movement in epidermal cells surrounding the infection foci of inoculated leaves (Mise and Ahlquist 1995), reduced rates of local spread in inoculated leaves, and restricted movement of the virus through the vascular system. Thus, these findings, and the fact that $\operatorname{CCMV}(\mathrm{B} 3 \mathrm{a})$ is able to establish systemic infections in $N$. benthamiana, a permissive host for both BMV and CCMV (Mise et al. 1993), supports the hypothesis that the bromovirus 3a MPs contribute substantially to hostspecific long-distance movement through the phloem.

Our observations are also consistent with recent findings that the MP of dianthovirus Red clover necrotic mosaic virus is associated with host-specific defects in long-distance transport. In this case, MP mutants are blocked at the bundle sheath and phloem parenchyma/companion cell-sieve element complex (Wang et al. 1998). Moreover, in tobamovirus and cucumovirus infections, the MP gene also contributes to hostspecific long-distance movement (Fenczik et al. 1995; Hilf and Dawson 1993; Kaplan et al. 1997). Thus, these data suggest that the plant virus MP is not only involved in cell-to-cell

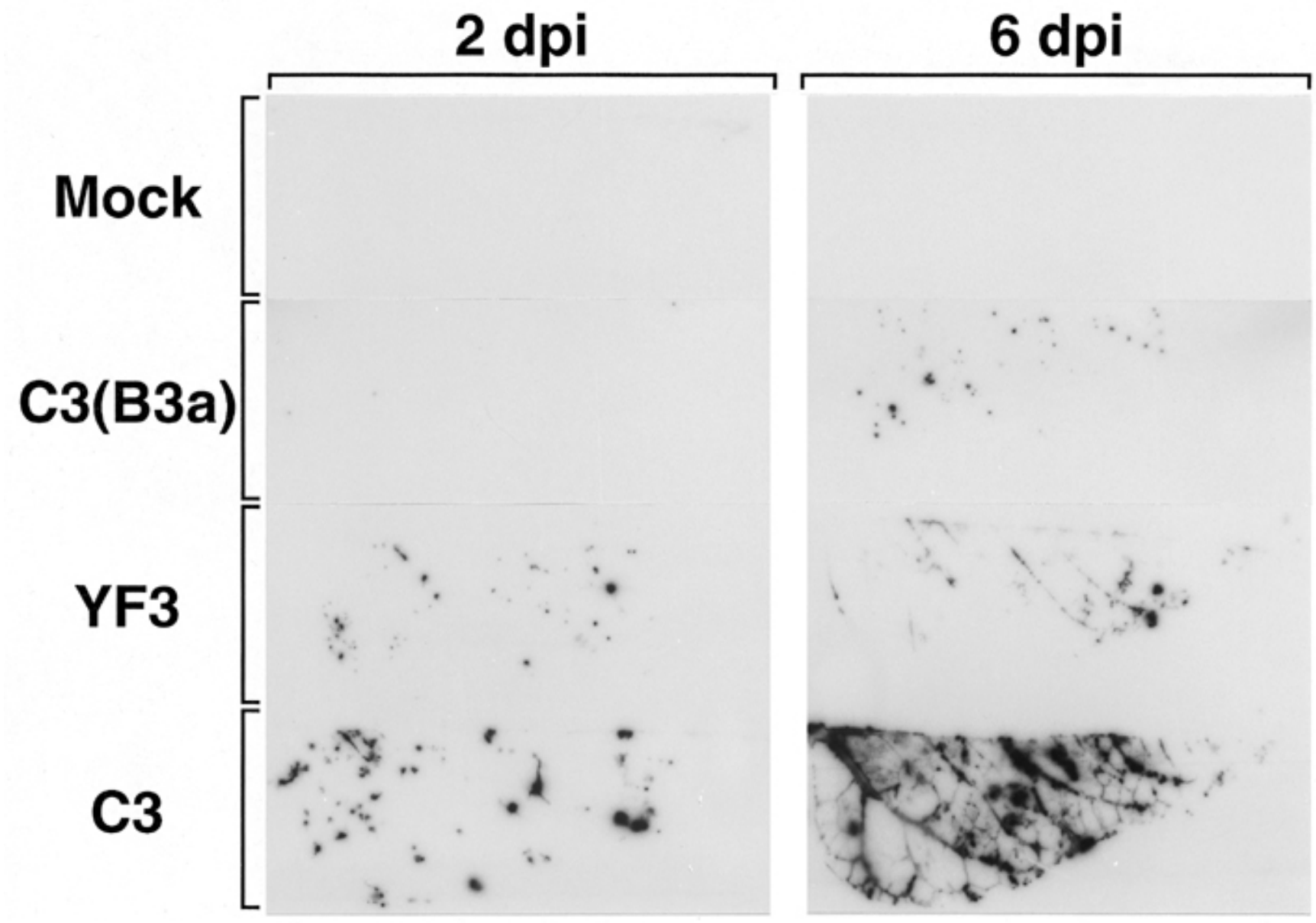

Fig. 4. Press-blotting analysis of inoculated cowpea leaves showing differences in the extent of viral spread at 2 and 6 days postinoculation (dpi). The adaxial epidermis of primary leaves of 7- to 9-day-old cowpea plants was inoculated with in vitro transcripts of $\mathrm{C} 1+\mathrm{C} 2$ and the RNA3s indicated to the left or with buffer (Mock). At 2 or $6 \mathrm{dpi}$, the lower epidermis of the half leaf was peeled off from the inoculated leaves and the leaf contents were blotted onto a nylon membrane. The membrane was hybridized with the same probe used in Figure 2 for detecting positive-sense RNAs. Autoradiograms shown were obtained by exposure of blots for $24 \mathrm{~h}$. These two series ( 2 and $6 \mathrm{dpi}$ ) of panels show samples pressed on the same membrane. 
movement but also has an important host-specific role in phloem-dependent long-distance movement. However, unlike the dianthovirus, tobamovirus, and cucumovirus CPs (Hilf and Dawson 1993; Taliansky and García-Arenal 1995; Xiong et al. 1993), bromovirus CPs appear not to mediate host specificity in long-distance movement (De Jong et al. 1995; Osman et al. 1997).

\section{Possible roles of A776C 3a adaptive mutation in overcoming host-specific restriction.}

We have shown that the A776C 3 a coding change that permits CCMV(B3a) to infect cowpea plants systemically (Fujita et al. 1996) also circumvented formation of reddish spots (Fig. $5 \mathrm{E}$ to $\mathrm{H})$. This suppression is correlated with faster spread of infection that enabled the virus to move in association with veins of inoculated cowpea leaves (Figs. 3 and 4). Taken together with previous in situ hybridization data indicating that the infection spread of hybrid $\operatorname{CCMV(B3a)~is~subjected~to~}$ host-specific restriction after the initial cell-to-cell movement in cowpea epidermal cells (Mise and Ahlquist 1995), we suggest that the A776C mutation may be directly or indirectly involved in overcoming defense responses that contribute to host-specific restriction.

Intriguingly, the MPs of other viruses such as tombusvirus Tomato bushy stunt virus (TBSV) and tobamovirus Tomato mosaic virus (ToMV) can elicit host defense reactions (Chu et al.
1999; Scholthof et al. 1995; Weber and Pfitzner 1998). Further, the avirulence determinants of the $T m-2$ and $T m-2^{2}$ resistances in tomato and $\mathrm{Nb}$ resistance in potato were mapped to the MP genes of ToMV and Potato virus $X$ (PVX), respectively (Malcuit et al. 1999; Meshi et al. 1989; Weber et al. 1993). These findings, and the former studies on the bromovirus $3 \mathrm{a}$ mutations associated with symptom phenotypes (Fujita et al. 1996; Rao and Grantham 1995), support the hypothesis that the bromovirus 3a MP gene regulates the ability to elicit host defense responses.

In contrast, our current observation, that the A776C mutation mediates suppression of symptom formation and enhances virus spread in cowpea plants, may suggest that the A776C mutation overcomes the host-specific restriction directly by enhancing the ability of the BMV 3a MP to support virus spread in cowpea. In this scenario, the suppression of symptom formation may be due in part to altered host-virus interactions that occur early in infections. This hypothesis may be supported as coinfection tests reveal that CCMV(B3a) does not induce a generalized defense response capable of limiting the A776C mutant (data not shown).

Furthermore, recent findings with $R x$-mediated resistance against PVX in potato demonstrated that necrotic lesion formation and pathogen arrest can result from separate disease responses in plants, suggesting the possibility that visible symptom formation is not always related to localization of

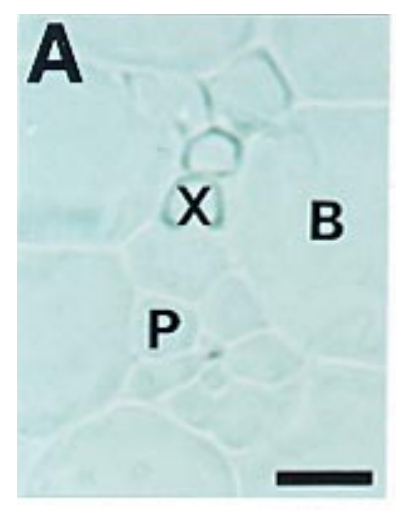

Mock

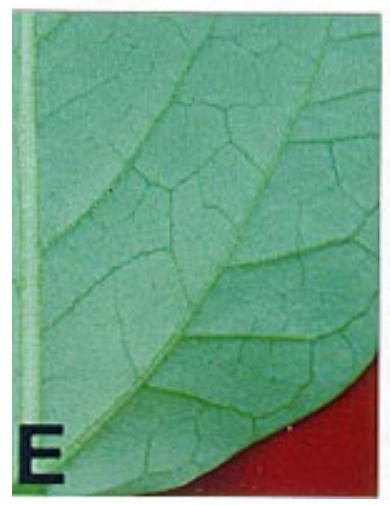

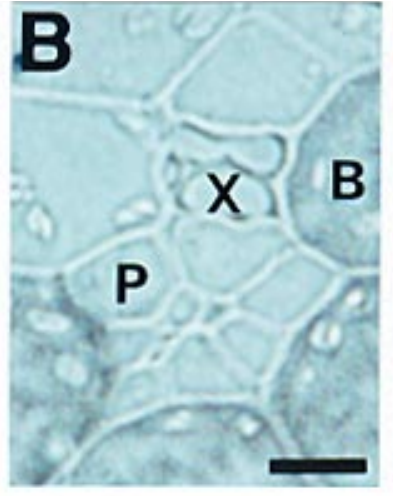
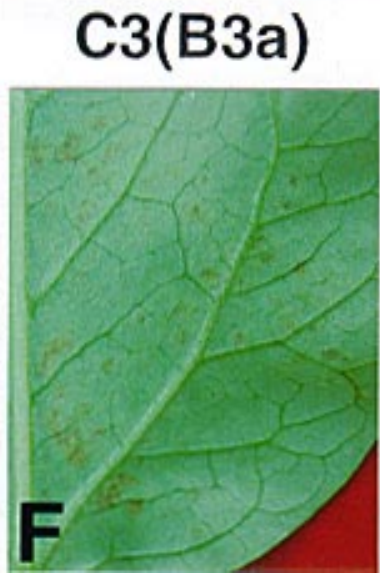

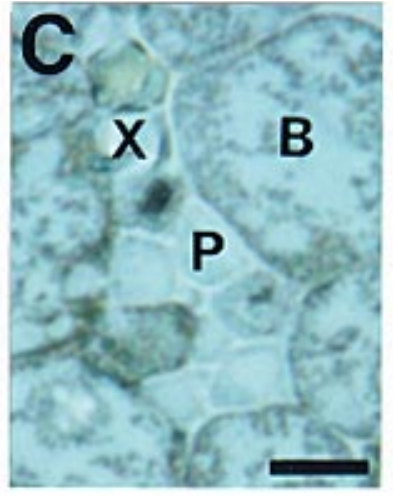

YF3

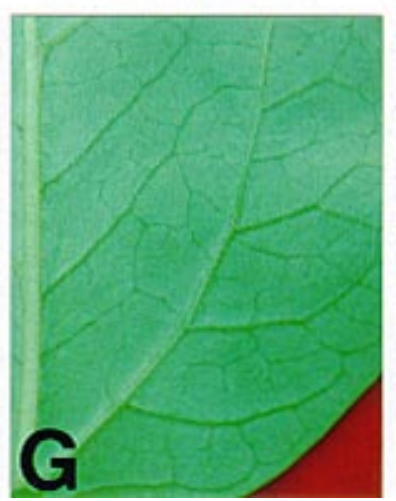

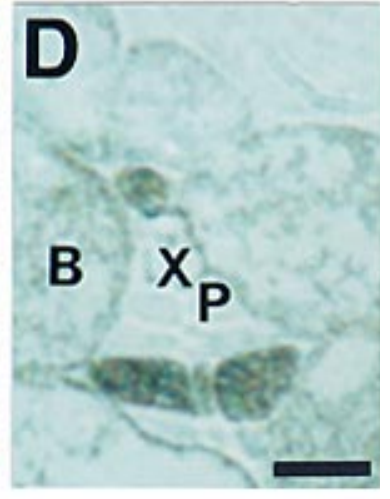

C3

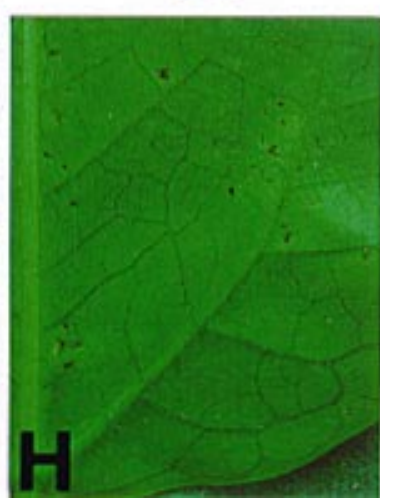

Fig. 5. Virus spread and pathogenesis in cowpea. A-D, Immunogold silver staining of Cowpea chlorotic mottle virus (CCMV) coat protein antigen in cross sections of forth-order veins of cowpea leaves inoculated with wild-type C3, YF3, or C3(B3a) and C1+C2. All samples were fixed 7 to 8 days postinoculation (dpi). A, Buffer (Mock); B, C3(B3a); C, YF3; and D, wild-type C3. B = Bundle sheath cell; P = phloem cell; and X = xylem. Bars indicate $10 \mu \mathrm{m}$ in A-D. E-H, Symptom phenotypes induced on the abaxial surface of the inoculated leaves of cowpea plants at 7 dpi. The adaxial epidermis of 7- to 9-day-old primary leaves were inoculated with $\mathbf{E}$, buffer (Mock) or with C1+C2 and F, C3(B3a); G, YF3; or H, C3. 
virus infection (Bendahmane et al. 1999). Also, the effects of mutations in the CMV 2a polymerase gene and the p22 MP gene of TBSV on virus infection phenotypes can be dissected from effects on induction of necrotic lesions (Chu et al. 1999; Kim and Palukaitis 1997). Taken together, further studies are required to clarify whether the A776C mutation is involved in the symptom phenotype, in the pathogen arrest phenotype, or both.

\section{MATERIALS AND METHODS}

\section{Viral cDNA clones.}

Viral cDNA clones, their in vitro transcripts, and progeny RNAs are referred to by their brief descriptive names, with laboratory designations following in parenthesis. $\mathrm{C} 1$ (pCC1TP1), C2 (pCC2TP2), and C3 (pCC3TP4) are wild-type cDNA clones of CCMV RNA1, RNA2, and RNA3, respectively (Allison et al. 1988). C3(B3a) (pBC3KM11), in which the $3 \mathrm{a}$ gene of CCMV is replaced by that of BMV, and YF3 (pBC3YF3), in which an A residue at position 776 of C3(B3a) is substituted for a $\mathrm{C}$ residue, have been described previously (Fig. 1) (Fujita et al. 1996; Mise et al. 1993).

\section{Inoculation of whole plants and analyses of progeny viral RNA.}

Cowpea (Vigna unguiculata cv. California Blackeye) plants were maintained in a growth room, as previously described (Fujita et al. 1996). Relative humidity ranged from 30 to $80 \%$. The synthesis of capped transcripts from XbaI-linearized, fulllength cDNA clones (Kroner and Ahlquist 1992), inoculation of cowpea plants with transcripts (Allison et al. 1988), extraction of total nucleic acids from cowpea leaves (Allison et al. 1990), preparation of samples for tissue-printing analysis (Mise et al. 1993), and Northern blot analysis of viral RNA accumulation (Kaido et al. 1995) were performed essentially as previously described. Press blotting of half-leaves follow the same procedures previously described (Mansky et al. 1990; Nagano et al. 1997), except for using two flat aluminum boards to apply pressure at 75 to $125 \mathrm{~g} / \mathrm{cm}^{2}$ for 3 to $5 \mathrm{~min}$. Radioactively labeled T3 RNA polymerase-derived transcripts from pCC3RA518 (Allison et al. 1990) are complementary to the 179 nucleotides conserved at the 3' end of all viral RNAs and were used as a probe to detect CCMV-specific RNAs in Northern blot, tissue-printing, and press-blot analyses. Northern blot hybridization signals were quantified with a digital radioactive imaging analyzer (Fujix BAS 2000; Fuji Photo Film, Tokyo).

\section{Tissue fixation, embedding, and sectioning.}

For detection of CCMV CP, tissues $(1 \times 8 \mathrm{~mm})$ containing reddish spots were randomly sampled from inoculated primary leaves at 7 to $8 \mathrm{dpi}$. Tissue fixation procedures were performed as described by van Lent and Verduin (1987), with the following modifications. Tissue samples were fixed under vacuum in $1 \%(\mathrm{wt} / \mathrm{vol})$ glutaraldehyde and $2 \%(\mathrm{wt} / \mathrm{vol})$ paraformaldehyde in $0.1 \mathrm{M}$ phosphate buffer, $\mathrm{pH} 7.0$, for 1 to $2 \mathrm{~h}$ on ice. After infiltration of the fixative, fixation proceeded for $16 \mathrm{~h}$ at $4^{\circ} \mathrm{C}$. The fixative was then discarded and the samples were washed six times for $10 \mathrm{~min}$ in buffer lacking glutaraldehyde and paraformaldehyde. The fixed samples were dehydrated by placing them in a graded series of ethanol (30 and 50\%, 10 min each; and 70, 90, 99, and 100\% twice, 20 min each) at room temperature $\left(20\right.$ to $\left.25^{\circ} \mathrm{C}\right)$. The ethanol was replaced with Technovit 7100 embedding resin (Heraeus Kulzer, Wehrheim, Germany) at room temperature and infiltration was conducted for $16 \mathrm{~h}$ at $4^{\circ} \mathrm{C}$. Tissue samples were transferred to gelatin capsules and resin was polymerized for 16 to $64 \mathrm{~h}$ at $4^{\circ} \mathrm{C}$ and for at least $2 \mathrm{~h}$ at room temperature. Semithin $(3-\mu \mathrm{m})$ sections were cut using glass knives on a Leica UCT ultramicrotome (Leica Microsystem AG, Vienna, Austria). Sections were transferred with tweezers onto drops of distilled water and dried onto amino propyl silane-coated glass slides (Matsunami, Osaka, Japan) at room temperature.

\section{Immunocytochemistry.}

Procedures for immunogold labeling were as previously described (van Lent and Verduin 1987), with the following modifications. Sections were first incubated for $30 \mathrm{~min}$ at room temperature in $1 \%$ bovine serum albumin (BSA) in phosphate-buffered saline (PBS: $8.1 \mathrm{mM} \mathrm{Na}_{2} \mathrm{HPO}_{4}, 1.5 \mathrm{mM}$ $\mathrm{KH}_{2} \mathrm{PO}_{4}, 0.137 \mathrm{M} \mathrm{NaCl}, 2.7 \mathrm{mM} \mathrm{KCl}$, and $3.1 \mathrm{mM} \mathrm{NaN}$ ), $\mathrm{pH} 7.4$, in a vertical staining jar. Drops $(10 \mu \mathrm{l})$ of primary antibody solution (1:3,000 dilution of rabbit polyclonal antiserum against BMV $\mathrm{CP}$ in PBS containing $0.05 \%$ Tween 20 and $1 \%$ BSA [PBST-BSA]) were placed onto the sections and the sections were incubated overnight at $4^{\circ} \mathrm{C}$. Anti-BMV-CP antiserum was used for detection of CCMV CP, because it has previously been demonstrated that anti-BMV-CP antiserum cross-reacts with CCMV CP in Western immunoblot analysis (Osman et al. 1997; our unpublished observation). After washing the slides three times (5 min each) in PBS containing $0.05 \%$ Tween 20 (PBST), drops $(10 \mu \mathrm{l})$ of secondary antibody solution (1:40 dilution of goat anti-rabbit immunoglobulin G conjugated to 5-nm-diameter gold [AuroProbe LM GAR; Amersham, Buckinghamshire, U.K.] in PBST-BSA) were placed onto the sections and incubated for $60 \mathrm{~min}$ at $37^{\circ} \mathrm{C}$. The slides were then washed three times as above, fixed for $15 \mathrm{~min}$ in $1 \%$ (wt/vol) glutaraldehyde in PBS, and washed three times ( 5 min each) in distilled water. Silver enhancement of gold labeling was conducted by adding $10 \mu \mathrm{l}$ of silver enhancing solution (IntenSE M; Amersham) to each section, followed by incubation for 6 to $18 \mathrm{~min}$ at room temperature. The sections were viewed and photographed in Olympus BX20 (Olympus, Tokyo, Japan) or Zeiss Axioskop (Carl Zeiss Jena, Jena, Germany) microscopes and dedicated cameras.

Table 1. Virus accumulation in different cell types in typical vascular bundles of cowpea leaves inoculated with movement protein mutants of Cowpea chlorotic mottle virus (CCMV) or wild-type CCMV

\begin{tabular}{lccc}
\hline & \multicolumn{3}{c}{ Number of vascular bundles $^{\mathbf{a}}$} \\
\cline { 2 - 4 } Inoculum & Examined & BS cells $^{\mathbf{b}}$ & Phloem cells $^{\mathbf{c}}$ \\
\hline C3 & 14 & $14(100)$ & $13(93)$ \\
YF3 & 12 & $12(100)$ & $11(92)$ \\
C3(B3a) & 30 & $27(90)$ & $15(50)$ \\
\hline
\end{tabular}

a Data based on light microscopy immunocytochemical detection of CCMV coat protein around and within third- and fourth-order veins in cross sections of cowpea primary leaves inoculated with wild-type $\mathrm{C} 3$, $\mathrm{YF} 3$, or $\mathrm{C} 3(\mathrm{~B} 3 \mathrm{a})$ and $\mathrm{C} 1+\mathrm{C} 2$. At 7 to 8 days postinoculation, tissues containing reddish spots were randomly sampled. Numbers in parentheses equal percentage of vascular bundles containing infected cells.

${ }^{\mathrm{b}}$ Bundles containing infected bundle sheath (BS) cells.

${ }^{c}$ Bundles containing infected phloem cells. Phloem cells contain phloem parenchyma and companion cells. 


\section{ACKNOWLEDGMENTS}

This work was supported in part by a Grant-in-Aid (06660051) for Scientific Research and a Grant-in-Aid (09NP1501) for Creative Basic Research from the Ministry of Education, Science, Sports, and Culture, Japan, and a Grant-in-Aid (JSPS-RFTF96L00603) from the "Research for the Future" program of the Japan Society for the Promotion of Science. YF and MF were supported by Research Fellowships of the Japan Society for the Promotion of Science for Young Scientists. We thank Takuji Yoshida (Takii Seeds Co. Ltd., Japan) for generously providing cowpea seeds (cv. California Blackeye); Manabu Miyagawa (Osaka Prefecture University, Sakai, Japan) for technical assistance of microscopy analysis; and Andy Jackson, Diane Lawrence, and Robin MacDiarmid (University of California, Berkeley) for comments made on the manuscript.

\section{LITERATURE CITED}

Allison, R. F., Janda, M., and Ahlquist, P. 1988. Infectious in vitro transcripts from cowpea chlorotic mottle virus cDNA clones and exchange of individual RNA components with brome mosaic virus. J. Virol. 62:3581-3588.

Allison, R. F., Thompson, C., and Ahlquist, P. 1990. Regeneration of a functional RNA virus genome by recombination between deletion mutants and requirement for cowpea chlorotic mottle virus $3 \mathrm{a}$ and coat genes for systemic infection. Proc. Natl. Acad. Sci. USA 87:1820-1824.

Atabekov, J. G., and Taliansky, M. E. 1990. Expression of a plant viruscoded transport function by different viral genomes. Adv. Virus Res. 38:201-248.

Bendahmane, A., Kanyuka, K., and Baulcombe, D. C. 1999. The $R x$ gene from potato controls separate virus resistance and cell death responses. Plant Cell 11:781-791.

Blackman, L. M., Boevink, P., Santa Cruz, S., Palukaitis, P., and Oparka, K. J. 1998. The movement protein of cucumber mosaic virus traffics into sieve elements in minor veins of Nicotiana clevelandii. Plant Cell 10:525-537.

Carrington, J. C., Kasschau, K. D., Mahajan, S. K., and Schaad, M. C. 1996. Cell-to-cell and long-distance transport of viruses in plants. Plant Cell 8:1669-1681.

Chu, M., Park, J.-W., and Scholthof, H. B. 1999. Separate regions on the tomato bushy stunt virus p22 protein mediate cell-to-cell movement versus elicitation of effective resistance response. Mol. Plant-Microbe Interact. 12:285-292.

Citovsky, V., and Zambryski, P. 1991. How do plant virus nucleic acids move through intercellular connections? Bioessays 13:373-379.

Cronin, S., Verchot, J., Haldeman-Cahill, R., Schaad, M. C., and Carrington J. C. 1995. Long-distance movement factor: A transport function of the potyvirus helper component proteinase. Plant Cell 7:549-559.

De Jong, W., Chu, A., and Ahlquist, P. 1995. Coding changes in the 3a cell-to-cell movement gene can extend the host range of brome mosaic virus systemic infection. Virology 214:464-474.

De Jong, W., Mise, K., Chu, A., and Ahlquist, P. 1997. Effects of protein mutations and reduced movement protein expression on infection spread by cowpea chlorotic mottle virus and its hybrid derivatives. Virology 232:167-173.

Deom, C. M., Lapidot, M., and Beachy, R. N. 1992. Plant virus movement proteins. Cell 69:221-224.

Ding, B. 1998. Intercellular protein trafficking through plasmodesmata. Plant Mol. Biol. 38:279-310.

Ding, B., Haudenshield, J. S., Hull, R. J., Wolf, S., Beachy, R. N., and Lucas, W. J. 1992. Secondary plasmodesmata are specific sites of localization of the tobacco mosaic virus movement protein in transgenic tobacco plants. Plant Cell 4:915-928.

Ding, B., Parthasarathy, M. V., Niklas, K., and Turgeon, R. 1988. A morphometric analysis of the phloem-unloading pathway in developing tobacco leaves. Planta 176:307-318.

Ding, X. S., Shintaku, M. H., Arnold, S. A., and Nelson, R. S. 1995. Accumulation of mild and severe strains of tobacco mosaic virus in minor veins of tobacco. Mol. Plant-Microbe Interact. 8:32-40.

Dufour, O., Palloix, A., Gebre Selassie, K., Pochard, E., and Marchoux, G. 1989. The distribution of cucumber mosaic virus in resistant and susceptible plants of pepper. Can. J. Bot. 67:655-660.
Fenczik, C. A., Padgett, H. S., Holt, C. A., Casper, S. J., and Beachy, R. N. 1995. Mutational analysis of the movement protein of odontoglossum ringspot virus to identify a host-range determinant. Mol. PlantMicrobe Interact. 8:666-673.

French, R., Janda, M., and Ahlquist, P. 1986. Bacterial gene inserted in an engineered RNA virus: Efficient expression in monocotyledonous plant cells. Science 231:1294-1297.

Fujita, M., Mise, K., and Furusawa, I. 1999a. Expression and characterization of the 3 a movement protein of cowpea chlorotic mottle bromovirus. Arch. Virol. 144:2449-2456.

Fujita, M., Mise, K., Kajiura, Y., Dohi, K., and Furusawa, I. 1998. Nucleic acid-binding properties and subcellular localization of the $3 \mathrm{a}$ protein of brome mosaic bromovirus. J. Gen. Virol. 79:1273-1280.

Fujita, Y., Mise, K., and Furusawa I. 1999b. Genotypic and phenotypic analysis of bromovirus adaptive mutants derived from a single plant. Microbiol. Immunol. 43:181-185.

Fujita, Y., Mise, K., Okuno, T., Ahlquist, P., and Furusawa, I. 1996. A single codon change in a conserved motif of a bromovirus movement protein gene confers compatibility with a new host. Virology 223:283-291.

Ghoshroy, S., Lartey, R., Sheng, J., and Citovsky, V. 1997. Transport of proteins and nucleic acids through plasmodesmata. Annu. Rev. Plant Physiol. Plant Mol. Biol. 48:27-50.

Gilbertson, R. L., and Lucas, W. J. 1996. How do viruses traffic on the "vascular highway"? Trends Plant Sci. 1: 260-268.

Goodrick, B. J., Kuhn, C. W., and Boerma, H. R. 1991a. Inheritance of nonnecrotic resistance to cowpea chlorotic mottle virus in soybean. J. Hered. 87:512-514

Goodrick, B. J., Kuhn, C. W., and Hussey, R. S. 1991b. Restricted systemic movement of cowpea chlorotic mottle virus in soybean with nonnecrotic resistance. Phytopathology 81:1426-1431.

Hilf, M. E., and Dawson, W. O. 1993. The tobamovirus capsid protein functions as a host-specific determinant of long-distance movement. Virology 193:106-114.

Hull, R. 1991. The movement of viruses within plants. Semin. Virol. 2:89-95.

Jansen, K. A., Wolfs, C. J. A. M., Lohuis, H., Goldbach, R. W., and Verduin, B. J. M. 1998. Characterization of the brome mosaic virus movement protein expressed in E. coli. Virology 242:387-394.

Kaido, M., Mori, M., Mise, K., Okuno, T., and Furusawa, I. 1995. Inhibition of brome mosaic virus (BMV) amplification in protoplasts from transgenic tobacco plants expressing replicable BMV RNAs. J. Gen. Virol. 76:2827-2833.

Kaplan, I. B., Gal-On, A., and Palukaitis, P. 1997. Characterization of cucumber mosaic virus III. Localization of sequences in the movement protein controlling systemic infection in cucurbits. Virology 230:343-349.

Kiberstis, P. A., Loesch-Fries, L. S., and Hall, T. C. 1981. Viral protein synthesis in barley protoplasts inoculated with native and fractionated brome mosaic virus RNA. Virology 112:804-808.

Kim, C.-H., and Palukaitis, P. 1997. The plant defense response to cucumber mosaic virus in cowpea is elicited by the viral polymerase gene and affect virus accumulation in single cells. EMBO J. 16:4060-4068.

Kroner, P., and Ahlquist, P. 1992. RNA based viruses. Pages 23-34 in: Molecular Plant Pathology. A Practical Approach. Vol. I. S. J. Gurr M. J. McPherson, and D. J. Bowles, eds. IRL Press, Oxford.

Lazarowitz, S. G., and Beachy, R. N. 1999. Viral movement proteins as probes for intracellular and intercellular trafficking in plants. Plant Cell 11:535-548.

Lucas, W. J., and Gilbertson, R. L. 1994. Plasmodesmata in relation to viral movement within leaf tissues. Annu. Rev. Phytopathol. 32:387-411.

Lucas, W. J., and Wolf, S. 1999. Connections between virus movement, macromolecular signaling and assimilate allocation. Curr. Opin. Plant Biol. 2:192-197.

Malcuit, I., Marano, M. R., Kavanagh, T. A., De Jong, W., Forsyth, A., and Baulcombe, D. C. 1999. The 25-kDa movement protein of PVX elicits $N b$-mediated hypersensitive cell death in potato. Mol. PlantMicrobe Interact. 12:536-543.

Mansky, L. M., Andrews, R. E., Jr., Durand, D. P., and Hill, J. H. 1990. Plant virus location in tissue by press blotting. Plant Mol. Biol. Rep. 8:13-17.

Maule, A. J. 1991. Virus movement in infected plants. Crit. Rev. Plant Sci. 9:457-473.

Meshi, T., Motoyoshi, F., Maeda, T., Yoshikawa, S., Watanabe, H., and 
Okada, Y. 1989. Mutations in the tobacco mosaic virus 30-kDa protein gene overcome Tm-2 resistance in tomato. Plant Cell 1:515-522.

Miller, W. A., Dreher, T. W., and Hall, T. C. 1985. Synthesis of brome mosaic virus subgenomic RNA in vitro by initiation on (-) sense genomic RNA. Nature 313:68-70.

Mise, K., and Ahlquist, P. 1995. Host-specificity restriction by bromovirus cell-to-cell movement protein occurs after initial cell-to-cell spread of infection in nonhost plants. Virology 206:276-286.

Mise, K., Allison, R. F., Janda, M., and Ahlquist, P. 1993. Bromovirus movement protein genes play a crucial role in host specificity. $\mathrm{J}$. Virol. 67:2815-2823

Murphy, F. A. 1996. Virus taxonomy. Pages 15-57 in: Fields Virology. B. N. Fields, D. M. Knipe, and P. M. Howley, eds. Lippincott-Raven, Philadelphia.

Nagano, H., Okuno, T., Mise, K., and Furusawa, I. 1997. Deletion of the C-terminal 33 amino acids of cucumber mosaic virus movement protein enables a chimeric brome mosaic virus to move from cell to cell. J. Virol. 71:2270-2276.

Nelson, R. S., and van Bel, A. J. E. 1998. The mystery of virus trafficking into, through and out of vascular tissue. Prog. Bot. 59:476-533.

Osman, F., Grantham, G. L., and Rao, A. L. N. 1997. Molecular studies on bromovirus capsid protein. IV. Coat protein exchanges between brome mosaic and cowpea chlorotic mottle viruses exhibit neutral effects in heterologous hosts. Virology 238:452-459.

Rao, A. L. N. 1997. Molecular studies on bromovirus capsid protein. III. Analysis of cell-to-cell movement competence of coat protein defective variants of cowpea chlorotic mottle virus. Virology 232:385-395.

Rao, A. L. N., and Grantham, G. L. 1995. A spontaneous mutation in the movement protein gene of brome mosaic virus modulates symptom phenotype in Nicotiana benthamiana. J. Virol. 69:2689-2691.

Santa Cruz, S. 1999. Perspective: Phloem transport of viruses and macromolecules - what goes in must come out. Trends Microbiol. 7:237-241.

Schaad, M. C., and Carrington, J. C. 1996. Suppression of long-distance movement of tobacco etch virus in a nonsusceptible host. J. Virol. 70:2556-2561.

Schmitz, I., and Rao, A. L. N. 1996. Molecular studies on bromovirus capsid protein. I. Characterization of cell-to-cell movement-defective RNA3 variants of brome mosaic virus. Virology 226:281-293.

Scholthof, H. B., Scholthof, K.-B. G., and Jackson, A. O. 1995. Identification of tomato bushy stunt virus host-specific symptom determinants by expression of individual genes from potato virus $\mathrm{X}$ vector. Plant Cell 7:1157-1172.

Séron, K., and Haenni, A.-L. 1996. Vascular movement of plant viruses. Mol. Plant-Microbe Interact. 9:435-442.

Taliansky, M. E., and García-Arenal, F. 1995. Role of cucumovirus capsid protein in long-distance movement within the infected plant. J. Virol. 69:916-922.

Thompson, J. R., and García-Arenal, F. 1998. The bundle sheath-phloem interface of Cucumis sativus is a boundary to systemic infection by tomato aspermy virus. Mol. Plant-Microbe Interact. 11:109-114.

van Lent, J. W. M., and Verduin, B. J. M. 1987. Detection of viral antigen in semi-thin sections of plant tissue by immunogold-silver staining and light microscopy. Neth. J. Plant Pathol. 93:261-272.

Wang, H.-L., Wang, Y., Giesman-Cookmeyer, D., Lommel, S. A., and Lucas, W. J. 1998. Mutations in viral movement protein after systemic infection and identify an intercellular barrier to entry into the phloemlong-distance transport system. Virology 245:75-89.

Weber, H., and Pfitzner, A. J. 1998. Tm- $2^{2}$ resistance in tomato requires recognition of the carboxy terminus of the movement protein of tomato mosaic virus. Mol. Plant-Microbe Interact. 11:498-503.

Weber, H., Schultz, S., and Pfitzner, A. J. P. 1993. Two amino acid substitutions in the tomato mosaic virus 30 -kilodalton movement protein confer the ability to overcome the $T m-2^{2}$ resistance gene in the tomato. J. Virol. 67:6432-6438.

Wintermantel, W. M., Banerjee, N., Oliver, J. C., Paolillo, D. J., and Zaitlin, M. 1997. Cucumber mosaic virus is restricted from entering minor veins in transgenic tobacco exhibiting replicase-mediated resistance. Virology 231:248-257.

Xiong, Z., Kim, K. H., Giesman-Cookmeyer, D., and Lommel, S. A. 1993. The roles of the red clover necrotic mosaic virus capsid and cell-to-cell movement proteins in systemic infection. Virology 192:27-32. 